\title{
Influence of operating conditions in the hydrogen production by steam reforming of methanol: numerical approach
}

\section{Influencia de las condiciones de operación en la producción de hidrógeno por reformado de metanol: aproximación numérica}

\author{
Leonardo Esteban Pacheco Sandoval ${ }^{1}$ (D), Carlos Alirio Díaz González ${ }^{(1 D)}$, Luis Eduardo Jaimes \\ Reatiga $^{1}$, Leidy Juliana Carrillo ${ }^{1}$, Brayan Andrés Díaz Joven ${ }^{1}$ \\ ${ }^{1}$ Ingeniería en Energía, GIRES: Recursos - Energía - Sostenibilidad, Universidad Autónoma de Bucaramanga, \\ Colombia

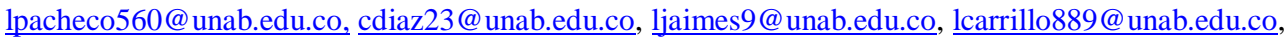 \\ bdiaz393@unab.edu.co
}

(Received: 10 August 2017, accepted: 14 September 2017)

\begin{abstract}
This work describes the unidimensional study of steam reforming of methanol at short pseudo-contact time. Steam reforming process (SRP) is important to hydrogen production as energetic vector. A compressible mathematical model 1-D is developed. Peppley kinetic mechanism (1999) is adopted. The numerical predictions show up the same trend as the experimental ones. A sensitivity analysis of the significant variables of the process is carried out (pressure, $\mathrm{CH}_{3} \mathrm{OH} / \mathrm{H}_{2} \mathrm{O}$ ratio and temperature).
\end{abstract}

Keywords: Methanol steam reforming, Hydrogen production, 1-D reactor model.

\begin{abstract}
Resumen. Este trabajo describe el estudio unidimensional del proceso de reformado de metanol en cortos tiempos modificados de residencia. El proceso Reformado de metanol es importante para la producción de hidrógeno como vector energético. Un modelo matemático 1-D del reactor es desarrollado. Se adopta el mecanismo cinético de Peppley (1999). Las predicciones numéricas muestran la misma tendencia de los datos experimentales. Un análisis de sensibilidad de las variables significativas del proceso es realizado (presión, relación $\mathrm{CH}_{3} \mathrm{OH} / \mathrm{H}_{2} \mathrm{O}$ y temperatura).
\end{abstract}

Palabras Clave: Reformado de metanol, producción de hidrógeno, Plug modelo reactor.

\section{Introduction}

The need for a rapid and accountable energy transition has been a focus of panel discussion and innovation in the last editions of the COP 21 Paris conference 2015; also, it is evident in the approach of the 17 objectives of the Organization of the United Nations to achieve sustainable development. In these current scenarios, the energy vector related to hydrogen and fuel cell technologies have a significant potential to enable this transition to a clean, low-carbon energy system. Implementing this technology still involves severe socio-economic and safety-related difficulties.

The low volumetric energy content of hydrogen and the nonexistent infrastructure for refueling present an obstacle for autonomy of hydrogen systems. Producing hydrogen via reformation of a liquid fuel shows potential problems from storage and transport of a much higher energy density liquid via the existing infrastructure [1-3] 
The significant storage problems in using hydrogen for transport applications must be solved before that is accepted as a widely used transportation fuel. In addition, hydrogen is not a primary energy source but an energy vector is it: chemical reactions must be used to extract it from hydrocarbons. Hydrogen can be produced from several hydrogen-rich primary fuels such as methanol, natural gas, ethanol or gasoline. These fuels are abundant, especially methane (hence methanol, since it can be produced from methane).

Being that carbon monoxide is a poison, hydrogen production by methanol steam reforming is more appropriate for this application because of $\mathrm{CO}$ production rate is a magnitude twice smaller than the other hydrogen production modes.

The table 1 shows up the principal characteristics of hydrogen production processes for several primary fuel rich in hydrogen. Table 1 allows to extract sufficient information regarding the methanol as the best option, argued by means of the reforming of steam that agrees to reach a good percentage of conversion to obtain hydrogen and additionally generates a small amount of $\mathrm{CO}$ with a temperature of the reaction between $500-600 \mathrm{~K}$ [1]. The $\mathrm{CO}$ is a poison for the fuel cell. The $\mathrm{C} / \mathrm{H}$ ratio for methanol is 0.25 , 0.7 to gasoline, 0.5 for diesel and 0.25 for methane. Additionally, methanol does not contain carboncarbon bonds.

Table 1. Characteristics of different processes for hydrogen production

\begin{tabular}{l|l|l|l}
\hline \multicolumn{2}{l|}{$\begin{array}{l}\text { Hydrogen } \\
{[\% \text { mol] }}\end{array}$} & CO [\% mol] & T [K] \\
\hline Steam reforming & 78 & 11.2 & $1000-1100$ \\
\hline Methane & 71.9 & 0.8 & $500-600$ \\
\hline Methanol & 71.5 & oct-14 & $800-1000$ \\
\hline Ethanol & 73.3 & 20 & $1000-1150$ \\
\hline Gasoline, gasoil, fuel & \multicolumn{3}{|l}{} \\
\hline Partial oxidation & 46.3 & 20 & $1500-1600$ \\
\hline Methane & 34 & 25 & $1150-1900$ \\
\hline Gasoline, diesel, fuel & \multicolumn{3}{l}{} \\
\hline
\end{tabular}

The present work shows the results of the simulation of the chemical kinetics of Peppley et al (1992a-b). Peppley's model is a comprehensible mechanism kinetic for steam reforming of methanol [1-3]. This model shows that there are there reactions in the steam reforming Process (SRP): Steam reforming of methanol (SRM), decomposition of methanol (DM) and water gas shift (WGS). A revision of literature shows the experimental result and the procedure.

\section{Reaction mechanisms of SRM}

The catalyst has an important role in the steam-reforming process (SRP) because has been studied the catalysts performance taking into account two parameters: methanol conversion and reducing of $\mathrm{CO}$ production.

Cooper-based catalyst has been largely studied for increase the methanol conversion, decrease the $\mathrm{CO}$ production and decrease the energy consumption in SRP. The $\mathrm{Cu} / \mathrm{ZnO} / \mathrm{Al}_{2} \mathrm{O}_{3}$ catalyst is the most suitable for SRP [4-13].

Comprehensible mechanism kinetic of Peppley et al [2, 3] had been reproducing for many authors [1, $13,14]$ with agreeable concordance between experimental results and numerical results. 
Different works had been carried for achieve a mechanism kinetic independent of operating conditions $[13,15]$.

Reaction mechanisms of SRM have been studied extensively. Jiang et al. (1993a-b) used a U-tube reactor (I.D. $6 \mathrm{~mm}$ ) maintained at atmospheric pressure and constant temperature. They developed a reaction mechanism in SRM by regression analysis of methanol synthesis in which the adsorption of $\mathrm{CH}_{3} \mathrm{OH}$ and $\mathrm{H}_{2}$ significantly affects the reaction rate; $\mathrm{CO}_{2}$ has no effect. Their infrared studies showed that competitive adsorption takes place between $\mathrm{CH}_{3} \mathrm{OH}$ and $\mathrm{CO}$ by which the $\mathrm{CH}_{3} \mathrm{OH}$ is preferentially adsorbed. The process is $100 \% \mathrm{CO}_{2}$ selective. The author considering unimportant the MD and WGS reactions. The author had also developed a model to predict the rates of formation of $\mathrm{CO}_{2}$ and $\mathrm{H}_{2}$, but this model did not predict $\mathrm{CO}$ formation; they showed CO formation experimentally at low temperatures [10, 13].

Agrell et al. (2002) used a tubular quartz reactor (I.D. $6 \mathrm{~mm}$ ) at atmospheric pressure with helium as the carrier gas. They assumed isothermal reaction conditions and negligible transfer resistance. He suggested that the $\mathrm{CO}$ is a secondary product formed at higher temperatures by a reversible WGS reaction and confirmed that the WGS reaction is favored by a lower pseudo-contact time and a higher temperature [9].

Purnama (2004) proposed a model that predicted the CO formation and studied the size catalyst particle influence. The author reports the negligible CO production by the MD and reversible WGS [12].

Peppley's et al. [5,6] reaction mechanism using numerical integration of a plug-flow tubular reactor model, assuming isothermal wall conditions and a pure methanol-steam feed. In Peppley's et al. [5, 6] model, these kinetic mechanisms were developed by measuring the $\mathrm{CH}_{3} \mathrm{OH}$ conversion percentage at the reactor entrance and exit (which was assumed isothermal). Thus, the temperature gradients in the reaction zone and the effect of reactant flow on the reactions were not considered. The kinetic mechanism proposed by Peppley et al. (1992a-b) present the advantage of predicting CO formation, which is not generally considered. The table 2 shows the experimental conditions used for this author [5,6].

Table 2 Experimental conditions of Peppley et al. $1999[5,6]$

\begin{tabular}{l|l}
\hline $\begin{array}{l}\text { Catalyst } \\
\mathbf{C u} / \mathbf{Z n O} / \mathbf{A L}_{2} \mathbf{O}_{3}\end{array}$ & BASF K3-110 \\
\hline $\mathrm{Sg}\left[\mathrm{m}^{2} \mathrm{~kg}^{-1}\right]$ & $102 \times 103$ \\
\hline Wcat $[\mathrm{kg}]$ & $77 \times 10-6$ \\
\hline $\mathrm{dp}[\mathrm{mm}]$ & 1 \\
\hline $\mathrm{dr}[\mathrm{mm}]$ & 22.1 \\
\hline Twall $[\mathrm{K}]$ & 553 \\
\hline $\mathrm{P}[$ bar $]$ & 1.16 \\
\hline $\mathrm{H}_{2} \mathrm{O} / \mathrm{CH}_{3} \mathrm{OH}$ & 1.36 \\
\hline
\end{tabular}

\section{Mathematical model}

The mathematical model has been developed by an axisymmetric reactor and the numerical simulations was carried out using the software Simulink-MatLab.

The model considers the following suppositions:

- Stationary state

- Negligible load losses

- Fixed bed temperature

- Negligible catalyst deactivation

- Leaky reaction rate limiting steps 
- Reagents in gas phase and perfectly mixed

Continuity equation given for each species:

$$
\frac{d F_{i}}{d z}=\theta_{c a t} \rho_{c a t} A \sum_{j} \dot{r}_{i j}
$$

Energy conservation equation:

$$
\frac{\mathrm{dT}}{\mathrm{dz}}=\frac{\theta_{\text {cat }}}{\rho_{\mathrm{g}} \mathrm{C}_{\mathrm{p}, \mathrm{g}} \mathrm{u}_{\mathrm{g}}} \mathrm{S}_{\mathrm{p}} \alpha\left(\mathrm{T}_{\mathrm{cat}}-\mathrm{T}\right)-\rho_{\mathrm{cat}} \sum_{\mathrm{j}} \Delta \mathrm{H}_{\mathrm{j}} \dot{\mathrm{r}}_{\mathrm{ij}}
$$

The physical properties of the mixture and species are thermos dependents.

$$
\begin{gathered}
\text { Density of the gaseous mixture: } \rho_{\mathrm{g}}=\frac{\sum \mathrm{P}_{\mathrm{i}} \mathrm{M}_{\mathrm{i}}}{\mathrm{RT}} \\
\text { Partial pressure: } \mathrm{P}_{\mathrm{i}}=\mathrm{P}_{\mathrm{op}} \mathrm{X}_{\mathrm{i}} \\
\text { CaloricCapacity: } \mathrm{C}_{\mathrm{p}, \mathrm{g}}=\sum \mathrm{C}_{\mathrm{p}, \mathrm{i}} \mathrm{X}_{\mathrm{i}} \\
\text { Gas mixture speed: } \mathrm{u}_{\mathrm{g}}=\frac{\mathrm{u}_{\mathrm{E}}}{\mathrm{s}} \\
\text { Coefficient of heat transfer: } \alpha=\frac{\mathrm{Nu} \lambda_{\mathrm{g}}}{\mathrm{d}_{\mathrm{p}}} \\
\text { Nusselt [28]: Nu }=2+0.6 \mathrm{Re}^{1 / 2} \mathrm{Pr}^{1 / 3} \\
\text { Reynolds number: } \operatorname{Re}=\frac{\rho_{\mathrm{g}} \mathrm{u}_{\mathrm{g}} \mathrm{d}_{\mathrm{p}}}{\mu_{\mathrm{g}}}
\end{gathered}
$$

Dynamic Viscosity [28]:

$$
\begin{gathered}
\mu_{\mathrm{g}}=\sum_{\mathrm{i}} \frac{\mathrm{X}_{\mathrm{i}} \mu_{\mathrm{i}}}{\sum_{\mathrm{j}} \mathrm{X}_{\mathrm{j}} \dot{\Phi}_{l]}^{\mu}} \\
\Phi_{i j}^{\mu}=\frac{\left[1+\left(\frac{\mu_{\mathrm{i}}}{\mu_{\mathrm{j}}}\right)^{\frac{1}{2}}\left(\frac{\mathrm{M}_{\mathrm{j}}}{\mathrm{M}_{\mathrm{i}}}\right)^{\frac{1}{4}}\right]^{2}}{\left[8\left(1+\frac{\mathrm{M}_{i}}{\mathrm{M}_{\mathrm{j}}}\right)\right]^{1 / 2}} \\
\text { Prandtl number: } \operatorname{Pr}=\frac{\mathrm{C}_{\mathrm{p}, \mathrm{g}} \mu_{\mathrm{g}}}{\lambda_{\mathrm{g}}}
\end{gathered}
$$


Thermal conductivity:

$$
\begin{gathered}
\lambda_{\mathrm{g}}=\sum_{\mathrm{i}} \frac{\mathrm{X}_{\mathrm{i}} \lambda_{\mathrm{i}}}{\sum_{\mathrm{j}} \mathrm{X}_{\mathrm{j}} \dot{\Phi}_{l j}^{\lambda}} \\
\Phi_{i j}^{\lambda}=\frac{\left[1+\left(\frac{\lambda_{\mathrm{i}}}{\lambda_{\mathrm{j}}}\right)^{\frac{1}{2}}\left(\frac{\mathrm{M}_{\mathrm{j}}}{\mathrm{M}_{\mathrm{i}}}\right)^{\frac{1}{4}}\right]^{2}}{\left[8\left(1+\frac{\mathrm{M}_{i}}{\mathrm{M}_{\mathrm{j}}}\right)\right]^{1 / 2}} \\
\text { Molar mass: } \mathrm{M}_{\mathrm{g}}=\frac{\mathrm{P}_{\mathrm{op}}}{\mathrm{RT} \rho_{\mathrm{g}}} \\
\text { Mass fraction: } \mathrm{Y}_{\mathrm{i}}=\frac{\mathrm{X}_{\mathrm{i}} \mathrm{M}_{\mathrm{i}}}{\mathrm{M}_{\mathrm{g}}}
\end{gathered}
$$

The conversion of methanol $\left(\mathrm{x}_{\mathrm{CH} 3 \mathrm{OH}}\right)$ is calculated based on the carbon balance, equation (17). The carbon monoxide selectivity $\left(\mathrm{S}_{\mathrm{CO}}\right)$ is given by the equation $(18)$.

$$
\begin{gathered}
\mathrm{x}_{\mathrm{CH} 3 \mathrm{OH}}=1-\frac{\left[\mathrm{CH}_{3} \mathrm{OH}\right]}{\left[\mathrm{CH}_{3} \mathrm{OH}\right]+\left[\mathrm{CO}_{2}\right]+[\mathrm{CO}]} \\
\mathrm{S}_{\mathrm{CO}}=\frac{[\mathrm{CO}]}{\left[\mathrm{CO}_{2}\right]+[\mathrm{CO}]}
\end{gathered}
$$

\section{Results and discussion}

Figure 1 shows up the result from Peppley et al. [5,6] comparing whit the present numerical predictions; furthermore, the rate of methanol in function of pseudo-contact time $\mathrm{M} / \mathrm{F}_{\mathrm{CH} 3 \mathrm{OH}}$ (catalyst mass over $\mathrm{CH}_{3} \mathrm{OH}$ molar flow ratio) for a temperature $(553 \mathrm{~K})$, a $\mathrm{H}_{2} \mathrm{O} / \mathrm{CH}_{3} \mathrm{OH}$ molar ratio of 1.36 and a pressure of 1.16 [bar]. Also, figure 1 shows up that the numerical predictions follow the experimental data from Peppley et al. [5,6]. Figure 2 shows the CO selectivity for the same operating conditions. Figure 2 shows an agreeable concordance between the numerical prediction and experimental data. Figures 1 and 2 shows that the $\mathrm{CH}_{3} \mathrm{OH}$ conversion and $\mathrm{CO}$ selectivity increase to the pseudo-contact time increase. If the pseudo-contact time increase. There are site actives of catalyst available that privileging the $\mathrm{CO}$ production by the MD reaction.

\section{Sensitivity analysis}

Figure 3 shows up the conversion rate of methanol as a function of the pseudo contact time at different temperatures. An increasing of $\mathrm{CH}_{3} \mathrm{OH}$ conversion is observed to temperature increase. Figure 4. Shows the percentage of carbon monoxide (CO) selectivity as a function of the pseudo contact time at different methanol/water molar ratios. An increasing of water/methanol molar ratio decrease the carbon monoxide (CO) selectivity. The water in excess favored the SRM reaction and the WGS reaction. The WGS reaction is a mechanism of cleaning of $\mathrm{CO}$. A water/methanol molar smaller than 1 privilege the DM 
reaction and large pseudo-contact time favored the reversible WGS reaction. The two reactions (rWGS and MD) increase the $\mathrm{CO}$ production.

The numerical approach is according to literature review [5,6,9,10,12,13].

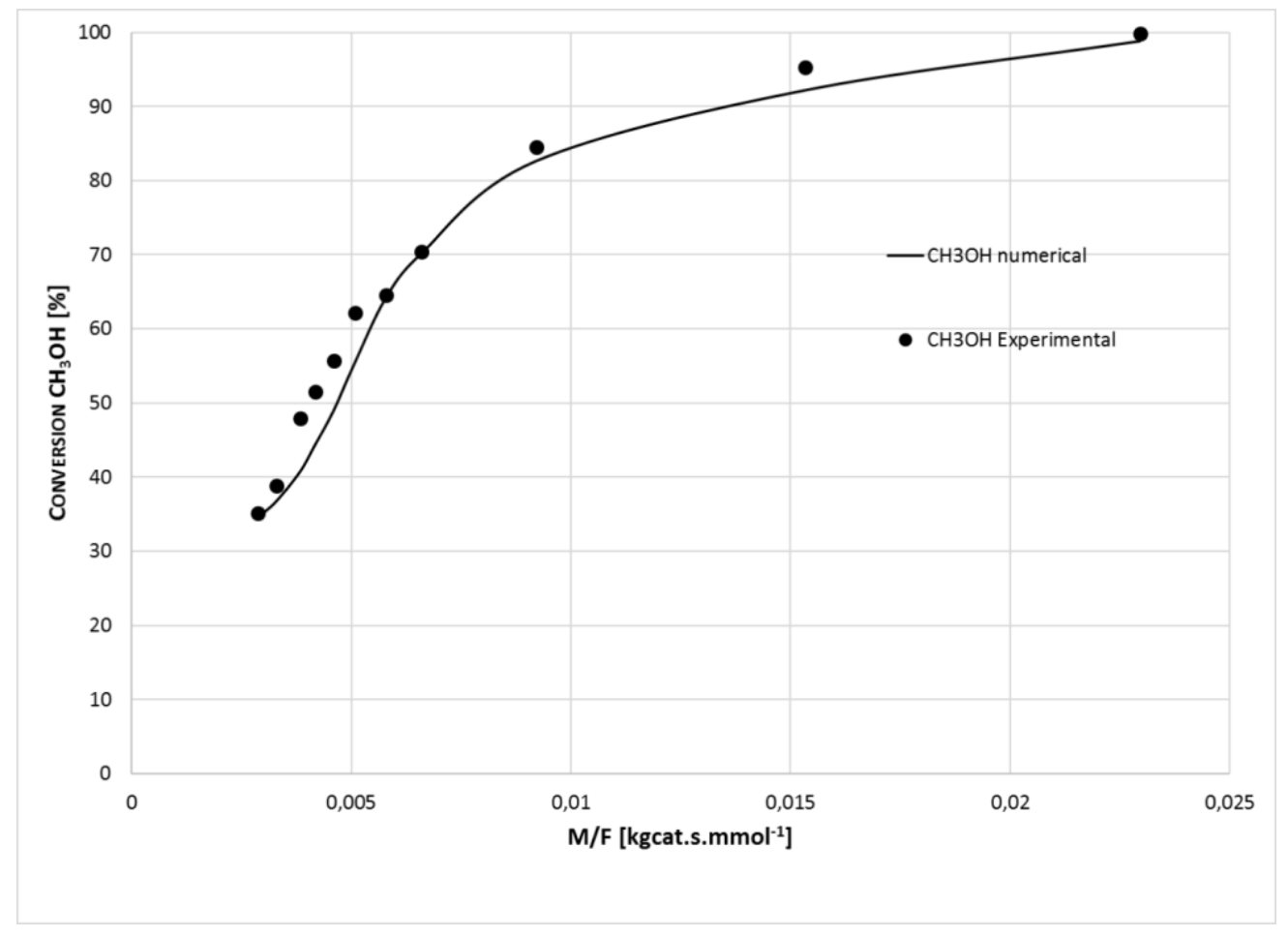

Figure 1. Conversion methanol rate in function of pseudo contact time

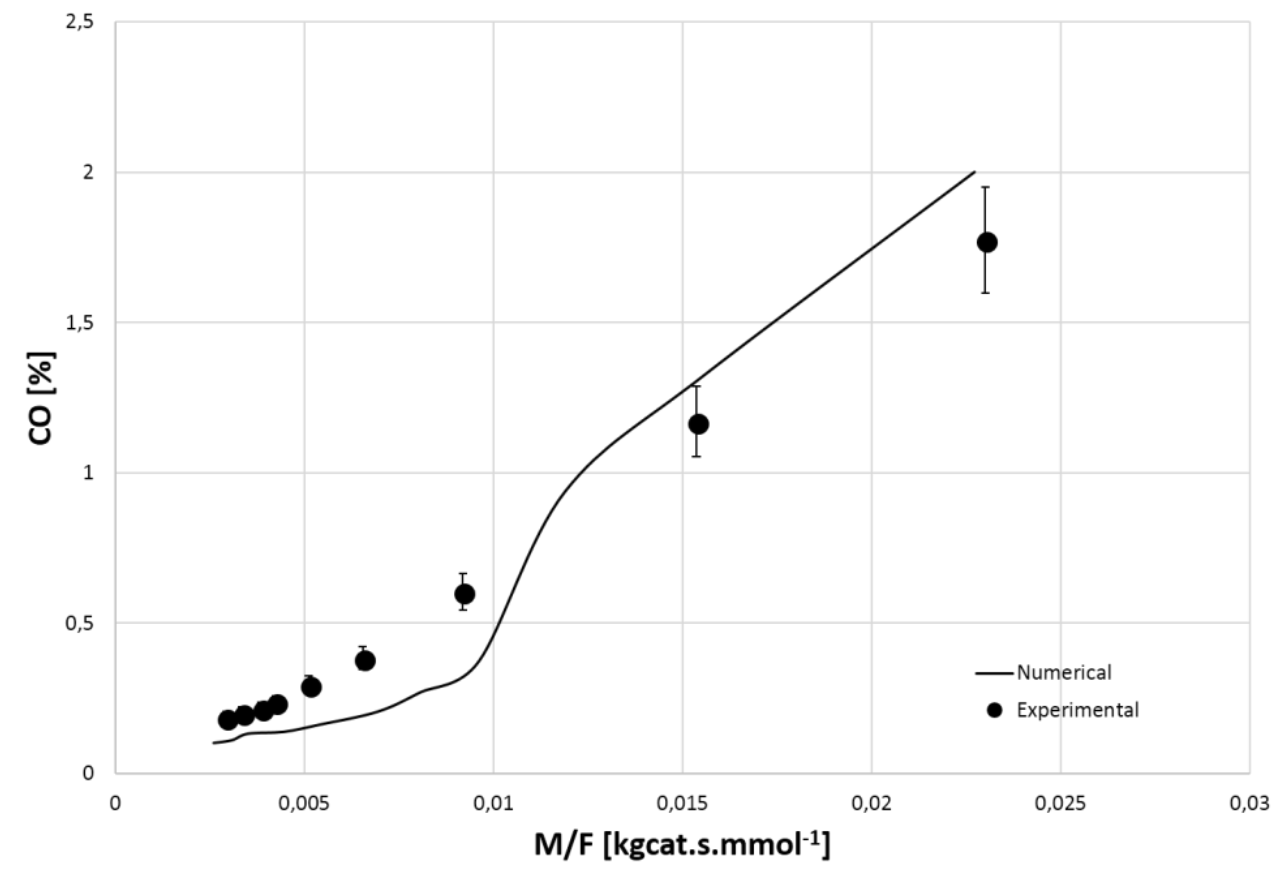

Figure 2. CO selectivity rate in function of pseudo contact time 


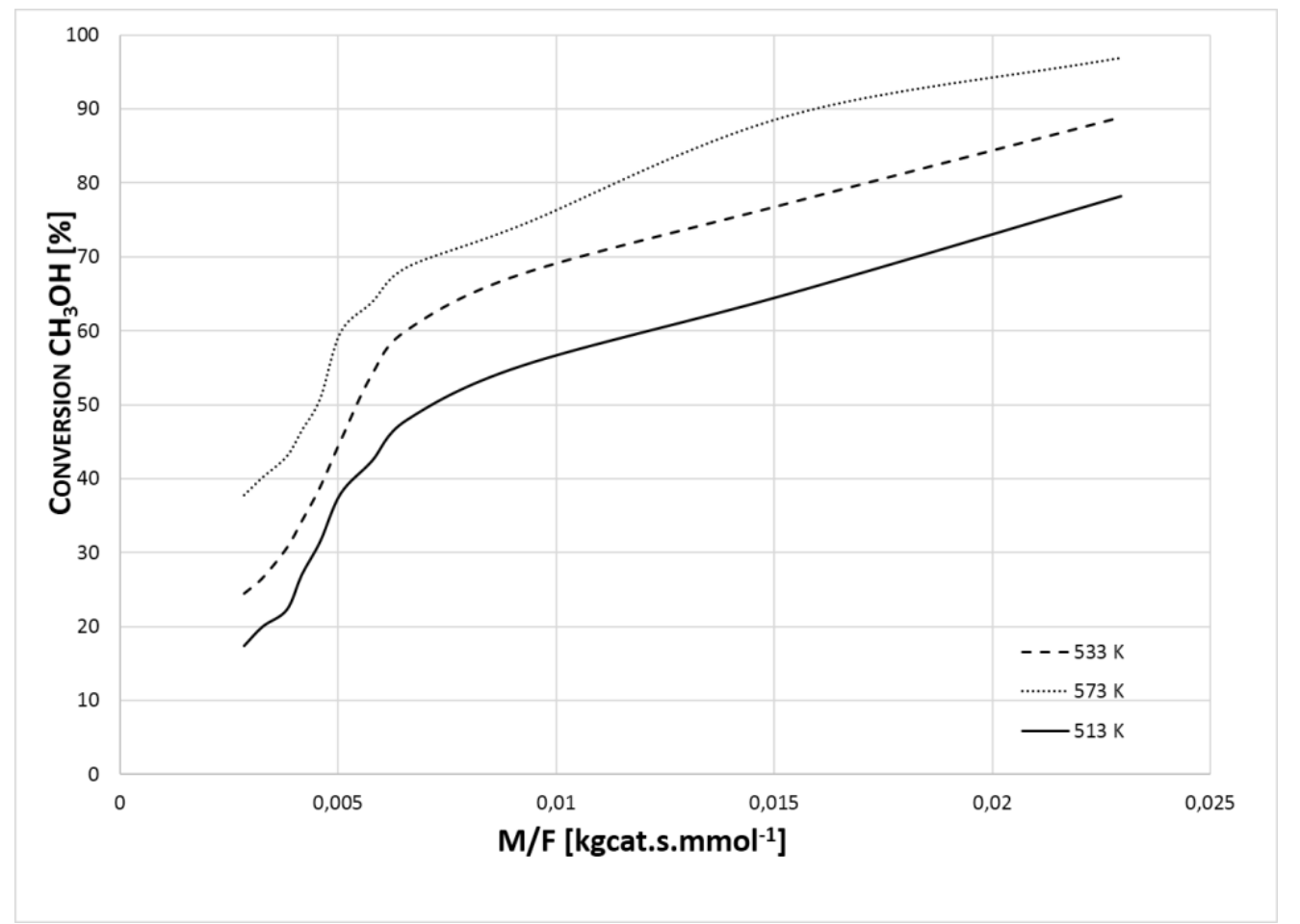

Figure 3. CO selectivity rate in function of pseudo contact time

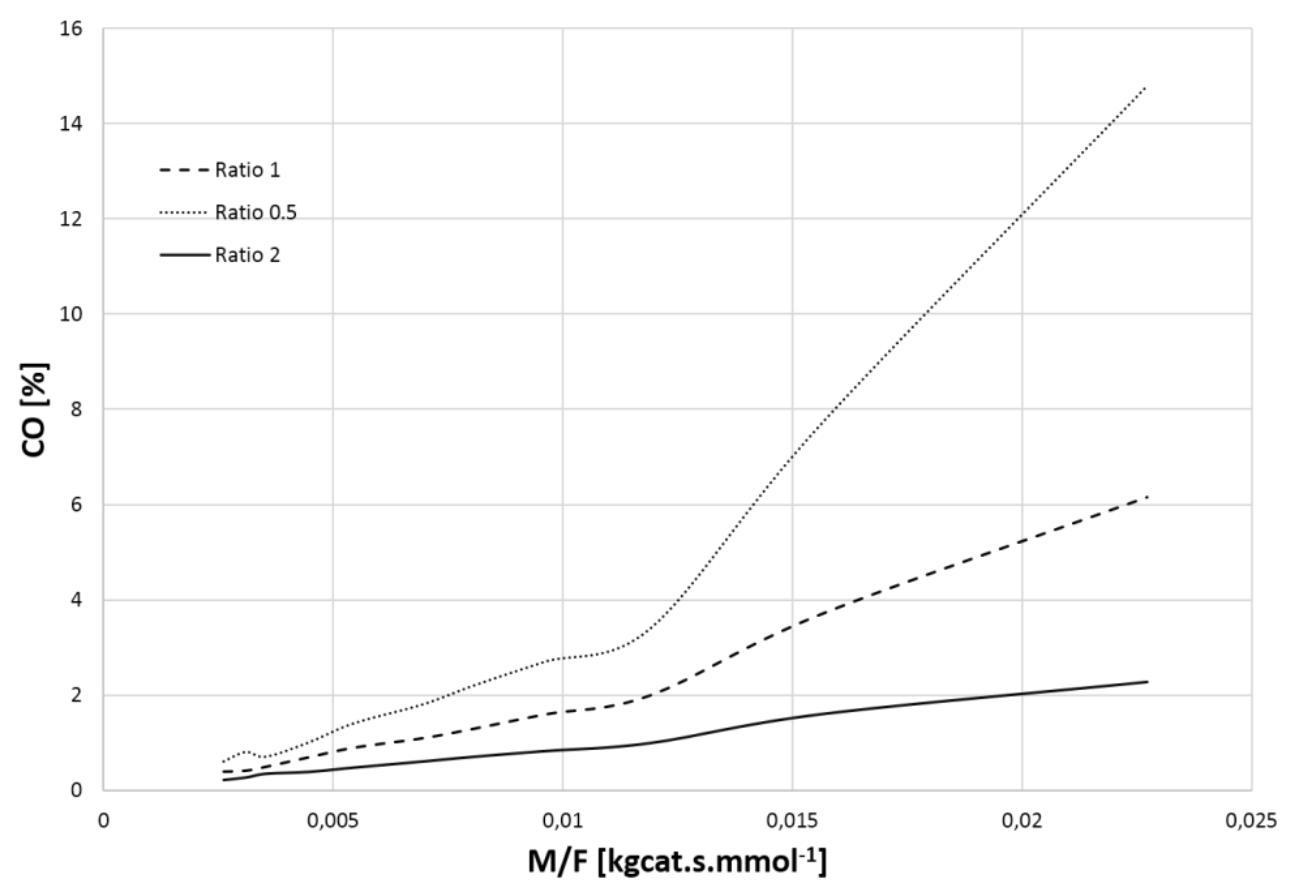

Figure 4. CO selectivity rate in function of pseudo contact time 


\section{Conclusion}

In this numerical approach, Peppley's kinetic $[5,6]$ has been used in a plug model for studying the rate of methanol conversion and the $\mathrm{CO}$ selectivity in function of pseudo-contact time. The model permits the prediction of methanol conversion and $\mathrm{CO}$ selectivity. An agreeable concordance between the numerical result and experimental data are obtained.

The approach numeric shows up that the methanol conversion is favoured whit an increase of temperature, and the $\mathrm{CO}$ selectivity decrease when the $\mathrm{H}_{2} \mathrm{O} / \mathrm{CH}_{3} \mathrm{OH}$ molar ratio increase. The methanol conversion and CO Selectivity are favoured to high pseudo-contact time.

\section{Nomenclature}

$\begin{array}{ll}\mathbf{F} & \text { Molar flow }[\mathrm{mol} / \mathrm{s}] \\ \mathbf{z} & \text { Length reactor }[\mathrm{m}] \\ \dot{\mathbf{r}} & \text { Rate of reaction }[\mathrm{mol} / \mathrm{s} . \mathrm{kgcat}] \\ \boldsymbol{\theta} & \text { Volumetric fraction of the catalyst in the reactor } \\ \boldsymbol{\rho} & \text { Density }[\mathrm{kg} / \mathrm{m} 3]\end{array}$

A Transversal section $\left[\mathrm{m}^{2}\right]$

T Temperature [K]

$\mathbf{C}_{\mathbf{p}} \quad$ Specific heat $[\mathrm{J} / \mathrm{mol} . \mathrm{K}]$

$\boldsymbol{\alpha} \quad$ Overall coefficient of heat transfer $\left[\mathrm{W} \cdot \mathrm{m}^{2} / \mathrm{K}\right]$

$\Delta \mathbf{H}_{\mathbf{j}} \quad$ Enthalpy of reaction $\mathrm{j}[\mathrm{J} / \mathrm{mol}]$

u Velocity $[\mathrm{m} / \mathrm{s}]$

$\mathbf{d}_{\mathbf{p}} \quad$ Catalytic bead size $[\mathrm{m}]$

$\mathbf{S}_{\mathbf{p}} \quad$ Catalyst specific surface[m] 


\begin{tabular}{|c|c|}
\hline$\varepsilon$ & Packed bed porosity \\
\hline $\mathbf{P}$ & Partial pressure $[\mathrm{Pa}]$ \\
\hline$M$ & Molar mass $[\mathrm{kg} / \mathrm{mol}]$ \\
\hline $\mathbf{R}$ & Gas constant $[\mathrm{J} / \mathrm{mol} . \mathrm{K}]$ \\
\hline $\mathbf{P}_{\text {op }}$ & Operating Pressure $[\mathrm{Pa}]$ \\
\hline $\mathbf{X}$ & Molar fraction \\
\hline $\mathrm{Nu}$ & Nusselt number \\
\hline$\lambda$ & Thermal conductivity $[\mathrm{W} / \mathrm{m} . \mathrm{K}]$ \\
\hline $\mathbf{R e}$ & Reynolds number \\
\hline Pr & Prandtl number \\
\hline $\boldsymbol{\mu}$ & Dynamic viscosity [Pa.s] \\
\hline $\mathbf{M}$ & Molar mass $[\mathrm{kg} / \mathrm{mol}]$ \\
\hline $\mathrm{x}_{\mathrm{CH} 3 \mathrm{OH}}$ & Conversion of methanol \\
\hline $\mathbf{S}_{\mathrm{CO}}$ & Selectivity of carbon monoxide \\
\hline $\mathbf{k}_{\mathbf{0}}$ & Kinetic constant $[\mathrm{mol} / \mathrm{Kg} . s . \mathrm{KPa}]$ \\
\hline $\boldsymbol{E} \boldsymbol{a}$ & Activation energy $[\mathrm{kJ} / \mathrm{mol}]$ \\
\hline 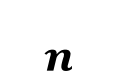 & Catalyst efficiency factor [-] \\
\hline
\end{tabular}




\section{Subscripts}

$\begin{array}{ll}\text { i } & \text { Species i } \\ \text { g } & \text { Gas mixture } \\ \text { e } & \text { into } \\ \text { cat } & \text { Catalyst }\end{array}$

\section{Referencias}

[1] Amphlett JC, Creber KAM, Davis JM, Mann RF, Peppley BA, Stokes DM. Hydrogen production by steam reforming of methanol for polymer electrolyte fuel cells. Int J Hydrogen Energy. 19:131-137. 1994.

[2] Mathiak J, Heinzel A, Roes J, Kalk T, Kraus H, Brandt H. Coupling of a $2.5 \mathrm{~kW}$ steam reformer with a $1 \mathrm{kWel}$ PEM fuel cell. J Power Sources. 131:112-119. 2004.

[3] Hong-Yue Tang, Jason Greenwood, Paul Erickson. Modeling of a fixed-bed copper-based catalyst for reforming methanol: Steam and autothermal reformation. 40, 8034-8050. 2015.

[4] L. Pacheco, D. Della-Valle, O. Le Corre, H. Habchi, T. Lemenand, H. Peerhossaini, "Modeling open flow steam reforming of metanol over $\mathrm{Cu} / \mathrm{ZnO} / \mathrm{Al} 2 \mathrm{O} 3$ vatalyst in an axisymmetric reactor". Journ. Appl. Fluid Mechanics.Vol 8, No 1, pp 33-42. 2015.

[5] Peppley B.A., J.C. Amphlett, L.M. Kearns, R.F. Mann, "Methanol-steam reforming on Cu/ZnO/AL2O3. Part 1: the reaction network". Appl. Catal. A: Gen. 179,21-29. 1999a.

[6] Peppley B.A., J.C. Amphlett, L.M. Kearns, R.F. Mann, "Methanol-steam reforming on Cu/ZnO/AL2O3 catalysts. Part 2: A comprehensive kinetic model". Appl. Catal. A: Gen 179, 31-49. 1999 b.

[7] Zhao T., K-D. Krever, T. Van-Nguyen, "Advances in Fuel Cells". Elsevier Ltd. 2007.

[8] Takeguchi T., Y. Kni, M. Inoue, K. Eguchi, "Steam reforming of methanol on copper catalysts supported on large-surface-area ZnAl2O3", Catal. Lett. 83 Nos 1-2. 2002.

[9] Agrell J., H. Birgersson, M. Boutonnet, "Steam reforming of methanol over a $\mathrm{Cu} / \mathrm{ZnO} / \mathrm{Al} 2 \mathrm{O} 3$ catalyst: a kinetic and strategies for suppression of CO formation". J. of Power Sources 106, 249-257. 2002.

[10] Jiang C.J., D.L. Trimm, M.S. Wainwright, "Kinetic study of steam reforming of methanol over copper-based catalysts". Appl. Catal. A: Gen. 93,245-255. 1993.

[11] Ranganathan E.S., S.K. Bej, L.T. Thompson," A methanol steam reforming over $\mathrm{Pd} / \mathrm{ZnO}$ and $\mathrm{Pd} / \mathrm{CeO} 2$ catalysts". Appl. Catal. 289,153-162. 2005.

[12] Purnama H., T. Ressler, R.E. Jentoft, H. Soerijanto, R. Schlögl, R. Schomäcker, "CO formation/selectivity for steam reforming of methanol with a commercial $\mathrm{CuO} / \mathrm{ZnO} / \mathrm{Al} 2 \mathrm{O} 3$ catalyst". Appl. Catal. A: Gen. 259,83-94. 2004.

[13] A. Iulianelli, P. Ribeirinha, A. Mendes, A. Basile. Methanol steam reforming for hydrogen generation via conventional and membrane reactors: A review. Renewable and sustainable Energy Reviews. 29, 355-368. 2014.

[14] Jiang C.J., D.L. Trimm, M.S. Wainwright, Kinetic mechanism for the reaction between methanol and water over a Cu/ZnO/Al2O3, Appl. Catal. A: Gen. 97,145-158. 1993b.

[15] S.T. Yong, C.W. Ooi, S.P. Chai, X.s. Wu. Review of methanol reforming-Cu-based catalysts, surface reaction mechanisms, and reaction schemes. International Journal of hydrogen energy. 30, 9541-9552. 2013.

\section{Sobre los autores}

\section{Leonardo Esteban Pacheco Sandoval}

Ph.D. Thermal Science and Energetic, M.Sc. Applied Mechanic: Propulsion systems. Full Professor Energy Engineering (UNAB). Interested on thermal system simulations, combustion internal engine, reactive systems, small hydro-power, energetic systems, environmental issues.

\section{Luis Eduardo Jaimes Reatiga}


M.Sc. Chemistry-Chemical Engineer. Associate Professor Energy Engineering (UNAB). Interested on Industrial processes, process safety, process simulation, HSE, life cycle assessment, environmental issues.

\section{Carlos Alirio Díaz Gonzalez}

M.Sc. Mechanical Engineer. Associate Professor Energy Engineering (UNAB). Interested on Thermodynamic analysis, exergy analysis, thermal system simulations, combustion, environmental issues.

\section{Leidy Juliana Carrillo - Brayan Andrés Díaz Joven}

Energy Engineering students. 